\title{
Examination of chromium-based coating properties deposited by means of TIG
}

\author{
Badania właściwości powłok na bazie chromu \\ napawanych metodą TIG
}

\author{
DOMINIK DUDEK \\ KONRAD STEFAŃCZYK \\ EWELINA SKOWRON \\ RADOSŁAW MIJAS *
}

DOI: https://doi.org/10.17814/mechanik.2017.11.179

\begin{abstract}
The paper presents results of the deposition tests on the steel plates made of X10CrMoNb9-1. The steel sheet has been TIGdeposited using two different materials. Welding process has been performed applying Electric Invertec V270-T pulse device. The materials used for the deposition were W CrMo2Si and $W$ CrMo91. After the process, samples have been cut from the deposited plates, from which the metallographic welds have been made. The paper presents photographs of microstructures recorded during observation of welds under Nikon Eclipse MA 200 inverted microscope.
\end{abstract}

KEYWORDS: superficial layer, deposition, coating, TIG deposition, microstructure

One of the directions of technological progress and development of material engineering is the search for alloys with high hardness and resistance to corrosion and abrasion. These searches are also determined by the economic factor.

There are many methods to improve the surface quality of a structural material (e.g. its roughness [1, 2], tribological properties, surface properties [3, 4]). They are applied on layers by electric discharge [5], as well as the use of: welding processes [6] (including hybrid welding or micro-welding [9-12]), laser technology [7, 8], thermal spraying [12]. An important element of the technological process is also the shaping and finishing process, since modern materials are difficult to process in general technologies. In this case, it is advisable to use unconventional technologies in shaping [13-15] or finishing [16].

Despite the development of construction materials, the hardfacing process is still an inherent part of many manufacturing processes. Wear of parts of machines, which results in deterioration of the useful properties of the work surfaces of these components, necessitates their replacement. This wear is due to the gradual loss of

\footnotetext{
* Dr inż. Dominik Dudek (dominik_dudek@op.pl) - Zakład Materiałoznawstwa i Technologii Amunicji, Politechnika Świętokrzyska; inż. Konrad Stefańczyk (konrad.stefanczyk@onet.pl) - MAN Bus Sp. z o.o.; mgr inż. Ewelina Skowron (ewelinanowak90@wp.pl), mgr inż. Radosław Mijas (mi-rad@wp.pl) - Mesko S.A.
}

material from the surface of the element resulting from its movement relative to the associated substance or other element, as well as to many physical and chemical processes occurring during operation. This issue is very complex. Replacing a used item usually involves high replacement costs. One of the ways to regenerate parts of machines that have been partially consumed is the hardfacing $[17,19]$.

Frequency of components replacement can be reduced by the use of materials with greater wear resistance. This feature can be achieved by applying to the material - e.g. by TIG hardfacing - a coating that improves its properties. The hardfacing process allows the components to be repaired or their wear resistance improved (e.g. excavator teeth, mining drills, cast iron pistons or lead-coated tanks used in the chemical industry). This reduces the cost of production and operation of machines and equipment.

\section{Hardfacing}

Hardfacing is a welding process aimed at metallurgical melting of a hardfaced surface and placing it on a molten substrate of a workpiece. This is important in view of achieving a suitable penetration depth, which determines the adhesion of the layer to the substrate material. The hardfacing process is designed to give the object proper properties such as wear resistance (especially abrasive) or corrosion. It can be used to regenerate parts improve its geometry and replenish losses caused by over-exploitation $[17,18]$.

An important parameter of the finished product is the contribution of the substrate in the hardfaced layer. This parameter depends on many factors, including the method of hardfacing and process parameters [17, 18].

Depending on the physics of the process, its implementation, and factors used for melting, many methods of hardfacing are distinguished. The TIG (tungsten inert gas) method is based on the arc hardfacing using a non-melting electrode within the gas shield. The additional hardfaced material is introduced into the arc area glowing between the non-melting tungsten electrode and the hardfaced substrate $[17,18]$. 


\section{Purpose and course of research}

The aim of the study was to investigate the hardfacing of $\mathrm{X} 10 \mathrm{CrMoNb9}-1$ steel by TIG method using highchromium electrodes. The chemical composition of steel is shown in table I.

For the manufacture of hardfaced layers, the following manufacturer's bars were used: W CrMo2Si and W CrMo91. Chemical composition of these materials is given in table II and table III.

TIG hardfacing was performed using the Electric Invertec V270-T pulse shown in fig. 1.

TABLE I. Chemical composition of steel X10CrMovNb9-1 [20]

\begin{tabular}{|c|c|c|c|c|c|c|c|}
\hline $\mathrm{C}$ & $\mathrm{Si}$ & $\mathrm{Mn}$ & $\mathrm{Cr}$ & $\mathrm{Mo}$ & $\mathrm{Ni}$ & $\mathrm{V}$ & Others \\
\hline $\begin{array}{c}0.08 \div \\
0.12\end{array}$ & $\begin{array}{c}0.2 \div \\
0.5\end{array}$ & $\begin{array}{c}0.3 \div \\
0.6\end{array}$ & $\begin{array}{c}8.0 \div \\
9.5\end{array}$ & $\begin{array}{c}0.85 \div \\
1.05\end{array}$ & $\begin{array}{c}0.06 \div \\
0.1\end{array}$ & $\begin{array}{c}0.18 \div \\
0.25\end{array}$ & $\begin{array}{c}0.03 \div \\
0.07\end{array}$ \\
\hline
\end{tabular}

TABLE II. Chemical composition of the hardfaced layer material made of CrMo2Si [19]

\begin{tabular}{|c|c|c|c|c|c|c|c|c|}
\hline $\mathrm{C}$ & $\mathrm{Mn}$ & $\mathrm{Si}$ & $\mathrm{Cr}$ & $\mathrm{Mo}$ & $\mathrm{P}$ & $\mathrm{As}$ & $\mathrm{Sb}$ & $\mathrm{Sn}$ \\
\hline 0.08 & 0.90 & 0.60 & 2.50 & 1.00 & $\leq 0.01$ & $\leq 0.01$ & $\leq 0.005$ & $\leq 0.006$ \\
\hline
\end{tabular}

TABLE III. Chemical composition of the hardfaced layer material made of CrMo91 [19]

\begin{tabular}{|c|c|c|c|c|c|c|c|}
\hline $\mathrm{C}$ & $\mathrm{Mn}$ & $\mathrm{Si}$ & $\mathrm{Cr}$ & $\mathrm{Mo}$ & $\mathrm{Ni}$ & $\mathrm{Nb}$ & $\mathrm{V}$ \\
\hline 0.1 & 0.3 & 0.5 & 9.0 & 0.9 & 0.5 & 0.06 & 0.2 \\
\hline
\end{tabular}

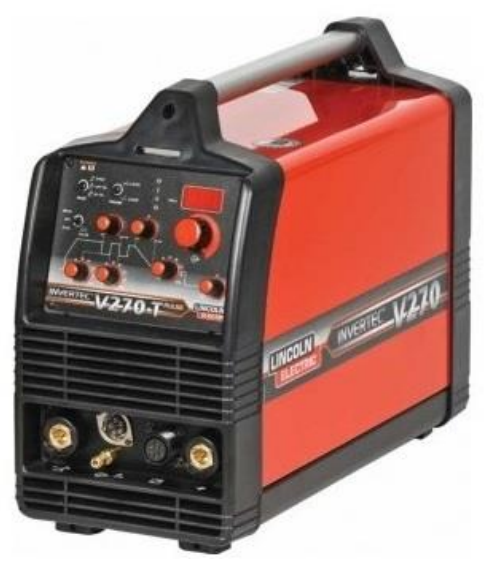

Fig. 1. Electric Invertec V270-T pulse

The hardfacing process was carried out in a protective gas shield - argon. Its flow rate was about $10 \mathrm{dm}^{3} / \mathrm{min}$, and the current was about $180 \mathrm{~A}$. After hardfacing, the metallographic observations and micro-hardness measurements were performed. The Nikon Eclipse MA 200 inverted metallographic microscope was used for observations, and NEXUS 4303 for micro-hardness measurement.

\section{Test results}

Analysis of observed and recorded microstructures of connections: hardfaced layer - native material, indicates that the material is very well combined with the substrate. The transition layer is characteristic for the hardfacing process and hardfaced coatings. Fig. 2 shows the microstructure of the connection of the hardfaced object in a variant, in which the hardfaced material was $\mathrm{W}$ CrMo2Si. The top layer of the substrate is one layer, while the other layer is composed of the hardfaced coating. Between them, there is also a layer with intermediate properties (degree of mixing of the substrate with the hardfaced material depends, among others, on the chemical composition of applied materials and the hardfacing parameters) and the heat transfer zone. Fig. 3 illustrates the microstructure of the connection of the hardfaced object in a variant, in which the W CrMo91 rod was hardfaced material.

The NEXUS 4303 was used for the measurement of micro-hardness. The average result of this measurement, made using the Vickers method, is presented in table IV (for variant with rod made of $\mathrm{W}$ CrMo2Si) and in table $\mathrm{V}$ (for variant with rod made of W CrMo91).

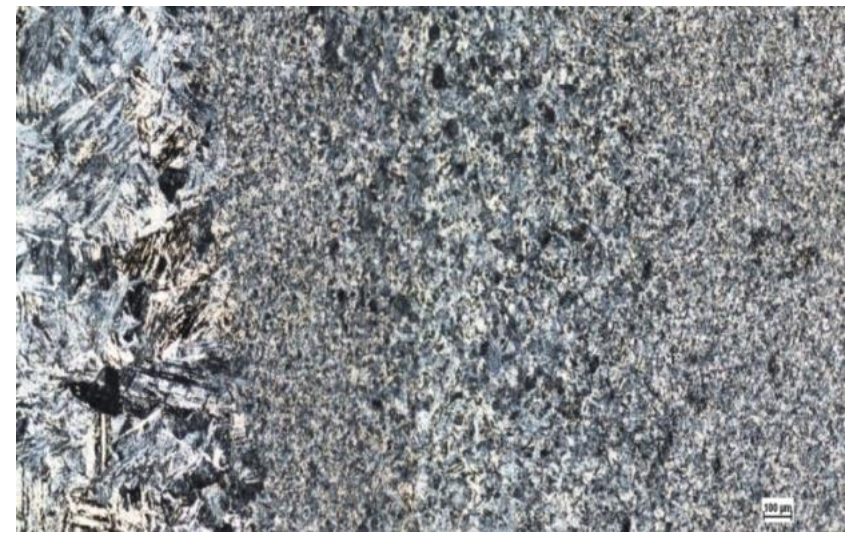

Fig. 2. Microstructure of the hardfaced connection made of rod W CrMo2Si with X10CrMoNb9-1 steel by means of TIG method in argon shielding

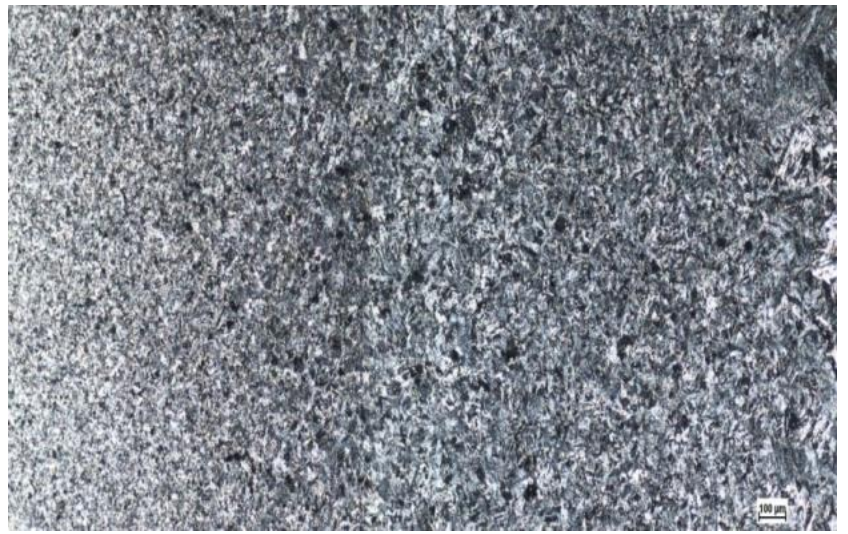

Fig. 3. Microstructure of the hardfaced connection made of rod W CrMo91 with X10CrMoNb9-1 steel by means of TIG method in argon shielding

TABLE IV. Average values of micro-hardness of the hardfaced layer, transition layer and native material (W CrMo2Si)

\begin{tabular}{|c|c|}
\hline Type of layer tested & Micro-hardness $\mathrm{HV}_{0,5}$ \\
\hline Hardfaced layer & 425 \\
\hline Transition layer & 440 \\
\hline Native material & 419 \\
\hline
\end{tabular}


TABLE V. Average values of micro-hardness of the hardfaced layer, transition layer and native material (W CrMo91)

\begin{tabular}{|c|c|}
\hline Type of layer tested & Micro-hardness $\mathrm{HV}_{0,5}$ \\
\hline Hardfaced layer & 459 \\
\hline Transition layer & 451 \\
\hline Native material & 424 \\
\hline
\end{tabular}

\section{Conclusions}

Hardfacing allows for increased wear resistance of the machine components and the regeneration of worn parts, thus significantly reducing production costs. This makes hardfacing an increasingly popular method in manufacturing processes. The technology is characterized by the precise metallurgical melting of the hardfaced coating with the molten substrate material.

Due to the TIG method, the hardfaced layer is characterized by a very good connection with the metal substrate, which results directly from the melting of the hardfaced with native material. In the microstructure of the TIG layer, there are four layers: hardfaced layer, transition layer, heat transfer zone and native material. The coating obtained does not contain pores or other defects if the hardfacing process has been carried out correctly. The proportion of the substrate in the hardfaced coating depends on many factors, among others, from the method of hardfacing applied by the operator and the chosen parameters and conditions of hardfacing. Composition and properties of the hardfaced layer and the native material - due to its melting change in a direction from the outer layer of the hardfaced layer to the native material.

\section{REFERENCES}

1. Nowicki B., Pierzynowski R., Spadło S. "The superficial layer of parts machined by brush electro discharge mechanical machining (BEDMM)". Journal of Engineering Manufacture. Part B. 218 (2004): pp. 9-15, DOI: 10.1243/095440504772830165.

2. Matuszewski M., Kałaczyński T., Łukasiewicz M., Musiał J. "Surface geometric structure after various treatments and wear process". The International Scientific Journal Problems of Tribology. 1 (2013): pp. 75-80.

3. Nowicki B., Pierzynowski R., Spadło S. "The electrodischarge-based surface alloying process using brush electrode". Proc. $12^{\text {th }}$ International Symposium for Electromachining (ISEM), VDI BERICHTE. 1405 (1998): pp. 289-298.

4. Nowicki B., Pierzynowski R., Spadło S. "New possibilities of machining and electrodischarge alloying of free-form surfaces". Journal of Materials Processing Technology. 109, 3 (2001): pp. 371-376, DOI:10.1016/S0924-0136(00)00828-1.

5. Nowicki B., Spadło S. "Brush electro-discharge mechanical machining BEDMM". International Symposium For Electromachining, Proceedings (ISEM-11). (1995): pp. 209216.

6. Dobranszky J. "The microwelding technologies and their applications". Budapest, 2004.

7. Mucha Z., Widlaszewski J., Kurp P. i in. "Mechanicallyassisted laser forming of thin beams". Laser Technology 2016.
Progress and Applications of Lasers. Book Series: Proceedings of SPIE. 10159, 2016.

8. Napadlek W. "The impact of the output stereometry and absorbent coating on the efficiency of ablative laser texturing of iron alloy 100CrMnSi6-4". Materials Testing. 57, 10 (2015): pp. 920-924.

9. Depczyński W., Młynarczyk P., Spadło S., Ziach E., Hepner $P$. "The selected properties of porous layers formed by pulse microwelding technique". METAL 2015: 24th International Conference on Metallurgy and Materials. (2015): pp. 10871092.

10. Chmielewski T.D., Golański D., Włosiński W., Zimmerman J. "Utilizing the energy of kinetic friction for the metallization of ceramics" Bulletin of the Polish Academy of Science: Technical Sciences. 63, 1 (2015): pp. 201-207, DOI: 10.1515/bpasts2015-0023.

11. Chmielewski T., Golański D. "New method of in-situ fabrication of protective coatings based on Fe-Al intermetallic compounds". Journal of Engineering Manufacture. 225, 4 (2011): pp. 611-616.

12. Krajewski A., Włosiński W., Chmielewski T., Kołodziejczak P. "Ultrasonic-vibration assisted arc-welding of aluminum alloys". Bulletin of the Polish Academy of Sciences: Technical Sciences. 60, 4 (2013): pp. 841-852.

13. Ruszaj A. "Nonconventional methods of machining machine elements and tools". Kraków: IOS, 1999.

14. Spadło S. "Comparative studies of brush electrodischarge machining with electrodes of alloy steel and tungsten". Advanced Manufacturing Systems and Technology (AMST 02), CISM Courses and Lectures. 437 (2002): s. 515-524.

15. Oniszczuk D., Świercz R. "An investigation into the impact of electrical pulse character on surface texture in the EDM and WEDM process". Advances in Manufacturing Science and Technology. 36, 3 (2012): pp. 43-53.

16. Bańkowski D., Spadło S. "The aplication of vibro-abrasive machining for smoothing of castings". Archives of Foundry Engineering. 17.1 (2017): pp. 169-173, DOI: 10.1515/afe-20170031.

17. Blicharski M. „Inżynieria powierzchni”. Warszawa: WNT, 2009.

18. Klimpel A. „Napawanie i natryskiwanie cieplne. Technologia". Warszawa: WNT, 2000.

19. Catalog by Benmet and Böhler Welding.

20. PN-EN 10088-1:2014-12 Stale odporne na korozję - Część 1: Wykaz stali odpornych na korozję. 